\title{
PLACENTAL TRANSFER OF THE LUPUS ERYTHEMATOSUS FACTOR
}

\author{
BY \\ DAVID BURMAN AND R. A. M. OLIVER \\ From Charing Cross Hospital, London, W.C.2
}

(RECEIVED FOR PUBLICATION APRIL 2, 1957)

Records of the placental transfer of the lupus erythematosus factor are scanty. We have been able to find two cases only in the literature (Bridge and Foley, 1954). They described a case where a woman suffering from acute systemic lupus erythematosus was successfully delivered of a normal child. The child remained clinically well, but the characteristic L.E. cells described by Hargraves, Richmond, and Morton (1948) were demonstrated in the blood at birth. The test gave a doubtful result after seven weeks and was negative at four months. They mention one other similar case but give no details.

The production of these cells is now recognized as due to a factor associated with the gammaglobulin fraction of the plasma. An instance is described where this plasma factor was present in the blood of a foetus aged 20 weeks, whose mother suffered from subacute systemic lupus erythematosus. Presumably this was the result of passive transfer of the L.E. factor across the placenta, since at necropsy the foetus showed no evidence of the disease.

\section{Case Report}

The patient was a 30-year-old housewife who was quite well until June, 1952, when she was four months' pregnant. She then noticed pain in the knees, ankles, and feet on movement. Subsequently these pains spread to other joints in the body. In September she developed a continuous, dull ache in the left shoulder accompanied by a pleuritic pain in the left lower chest. There was general malaise and excessive sweating at this time. Two weeks before delivery she developed precordial discomfort which was worse on lying flat. At full term, on October 30, she was delivered of a normal female child, weighing 5 lb. $7 \mathrm{oz}$.

After delivery she ran a continuous fever. On examination on November 15 she had the classical signs of a pericardial effusion which was confirmed radiologically. The B.S.R. was $145 \mathrm{~mm}$. (Westergren) in the first hour and aspiration of the pericardial fluid showed a straw-coloured fluid with a preponder- ance of lymphocytes. On November 21 she became breathless and was found to have bilateral pleural effusions confirmed radiologically and by aspiration. On December 4 an erythematous rash was noticed on the trunk and all four limbs, and on January 1, 1953, Hess's capillary test was positive. The Mantoux reaction was persistently negative and repeated examinations failed to demonstrate L.E. cells. On May 27, however, one L.E. cell was discovered and one month later moderate numbers were confirmed. On June 1 a course of cortisone was started, being continued with a maintenance dose of $25 \mathrm{mg}$. three times daily. On this treatment she gained weight, the B.S.R. (Westergren) fell to $24 \mathrm{~mm}$. in the first hour, and her general health improved so that she was able to manage to care for her child and home except for the heavy housework.

In the second pregnancy, which was started against medical advice, she complained of increasing joint pains and her B.S.R. (Westergren) was found to be $112 \mathrm{~mm}$. in one hour. Abdominal hysterotomy was undertaken by Mr. H. G. E. Arthure on January 28, 1956, when the patient was 20 weeks pregnant. Examination of the mother's blood at the time of operation showed approximately one L.E. cell per 500 white cells, and the direct Coombs test was positive in five minutes. The Kahn reaction was positive, but the Wassermann reaction was doubtful, showing a negative reaction with standard antigen and a weekly positive reaction with cardiolopin antigen.

Examination of the blood from the umbilical vein of the foetus showed occasional L.E. cells (less than 1 per 1,000 white cells) and the direct Coombs test was positive in five minutes. Both the Kahn and Wassermann reactions were negative. Filter-paper electrophoresis showed a heavy gamma globulin band in the mother's serum, but this was absent in the amniotic fluid and in the foetal serum.

At necropsy, the foetus appeared normal for the period of gestation with no evidence of the characteristic fibrinoid necrosis in the arterioles or connective tissue of the body including the spleen, kidneys, myocardium, skin, and placenta.

The patient improved clinically, but examination for L.E. cells showed 3 per 200 white cells on February 10 and 10 per 200 white cells on April 25 (three months after operation). On her readmission 
to hospital in August, 1956, for investigation of lumbo-sacral pain, she was found to be running an intermittent fever with a B.S.R. (Westergren) of $119 \mathrm{~mm}$. in the first hour. Examination for L.E. cells showed 14 per 500 white cells.

\section{Comment}

In this case the investigations show that the test for L.E. cells and the direct Coombs test were positive in both the mother's serum and that of the foetus; the Kahn and Wassermann reactions were positive in the mother only (see Table).

TABLE

BLOOD FINDINGS IN FOETUS AND MOTHER COMPARED

\begin{tabular}{l|c|c|c|c|c}
\hline & $\begin{array}{c}\text { L.E. } \\
\text { Cells }\end{array}$ & $\begin{array}{c}\text { Coombs } \\
\text { Test }\end{array}$ & W.R. & $\begin{array}{c}\text { Kahn } \\
\text { Reaction }\end{array}$ & $\begin{array}{c}\text { Gamma } \\
\text { Globulin* }\end{array}$ \\
\hline $\begin{array}{l}\text { Foetus } \\
\text { Mother }\end{array}$ & $\begin{array}{c}\text { Present } \\
,\end{array}$ & - & - & - & $\begin{array}{c}\text { Absent } \\
\text { Present }\end{array}$ \\
\hline
\end{tabular}

* The presence of gamma globulin refers to a visible band on serum electrophoresis.

These results can be explained by passive transfer across the placenta, but the antibodies responsible for these different phenomena appear to cross the placental barrier independently of one another. The transfer of the factor producing a positive direct Coombs test in this condition may obviously cause difficulty in the diagnosis of haemolytic disease of the newborn.

To decide whether to terminate pregnancy in a case of systemic lupus erythematosus is difficult. Many cases start during pregnancy (Guion and Adams, 1943 ; Graffin, Taylor, and Hass, 1949 ; Ellis and Bereston, 1952 ; Smith, 1952 ; Cohen and Cadman, 1953 ; Harvey, Shulman, Tumulty, Conley, and Schoenrich, 1954). Moreover, Ellis and Bereston (1952) found that the disease became worse during pregnancy in 28 out of 69 cases. The disease started in our patient during her first pregnancy and became worse during the early weeks of her second. However, some cases improve during pregnancy but become worse in the puerperium (Guy, 1952; Harvey et al., 1954). From a study of the literature only one factor has been discovered which allows a prediction of the effect of pregnancy, or its termination, on the disease; this is the effect of a previous pregnancy. For instance, Rothman (1952) cites a case in which symptoms recurred during the first trimester of three successive pregnancies followed by rapid improvement after abortion, which was either spontaneous or induced therapeutically. This patient, like that reported by Shearn and Pirofsky (1952), improved, but Harvey et al. (1954) report cases in which therapeutic abortion led to no improvement.

Although antibodies have been found in the foetus on two previous occasions when systemic lupus erythematosus occurs during pregnancy, no characteristic pathological changes have yet been reported. The high rate of foetal loss $(32 \%)$ reported by Ellis and Bereston (1952) would thus appear to be due to maternal causes, rather than to a direct effect of the disease on the foetus.

We wish to thank Dr. N. S. Plummer for permission to study this patient and for much helpful advice and criticism, and Dr. John Shore for his necropsy report.

\section{Addendum}

Since submitting this article Berlyne, Short, and Vickers (1957) have described two further instances of placental transfer of the L.E. factor. In both cases L.E. cells were demonstrable in mother and foetus. The infants remained healthy, L.E. cells disappearing from the blood by seven weeks.

\section{REFERENCES}

Berlyne, G. M., Short, L. A., and Vickers, C. F. H. (1957). Lancet, 2,15 .

Bridge, R. G., and Foley, F. E. (1954).Amer. J. med. Sci., 227, 1 Cohen, H., and Cadman, E. F. B. (1953). Lancet, 2, 305.

Ellis, F. A., and Bereston, E. S. (1952). A.M.A.Arch. Derm. Syph. 65, 170 .

Graffin, J. W., Taylor, C. B., and Hass, G. M. (1949). Med. clin. N. Amer., 33, 79

Guion, C. M., and Adams, E. C. (1943). Amer. J. med. Sci., 205, 33 Guy (1952). Quoted by Ellis and Bereston (1952).

Hargraves, M. M.. Richmond, H., and Morton, R. (1948). Proc. Mayo Clin., 23, 25.

Harvey, A. M., Shulman, L. E., Tumulty, P. A., Conley, C. L., and Schoenrich, E. H. (1954). Medicine (Baltimore), 33, 291.

Rothman (1952). Quoted by Ellis and Bereston (1952).

Shearn, M. A., and Pirofsky, B. (1952). Arch. intern. Med., 90, 790. Smith, P. A. J. (1952). Brit. J. Derm., 64, 10. 